\title{
RAD52 wt Allele
}

National Cancer Institute

\section{Source}

National Cancer Institute. RAD52 wt Allele. NCI Thesaurus. Code C106264.

Human RAD52 wild-type allele is located within 12p13-p12.2 and is approximately $79 \mathrm{~kb}$ in length. This allele, which encodes DNA repair protein RAD52 homolog, plays a role in both homologous recombination and DNA repair. 